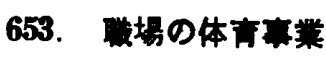

一特にプロタラムサービスについてー 早稲田大学教育学都 梅 沢 宣 婎

I. 研究目的これまで学校中心水えられてきた体育 事業に関する理論が，職胁の体育経営の場合どのよ5に

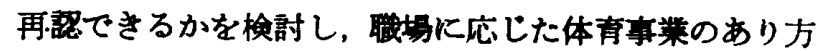
を究明する。

II. 研究内容今回は特飞体育事莱のなかからプログラ ムサービス (P.S.) をとりあげ, P.S. の運営条件のちが いと運動者行動の関係について検討した.

III. 研究方法 従業員 3,000 人前後の生産工場を有す

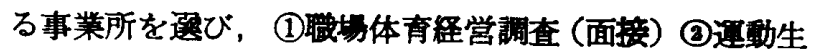
活調查（各事業所約 500 人，質問紙法）の結果によって 検討した。

IV. 結果の概要及ひ考宩 1. P.S. 運営の実態.

(1) P.S. の種類・性格と実施回数.K社:年間 18 回. 競找プロ (Ath. P.) のみ. O 社：8回. Ath. P.とレ クリエーションプロ (Rec. P.) の2在. B 社: Ath.P. とRec. P.の2值. S 社: Ath. P., Rec. P. 学習プ ロ、トレーニングプロ，及びテストプロの 5 種を実施.

（2）参加（動員）方式 部祼〜プロック単位が王倒的 に多い中で， $\mathrm{S}$ 社が個人の自由参加方式中心. B と S
社に年令制限中技能段階別あり．学校の場合にみられる 「個人の選択強制」方式は1つるなかった。

(3) 運営組䋘・計画的活動，K：企画・運営ともク ブ依存. $\mathrm{O}:$ 厚生・文体委・クラブ・学組・健保・寮 自治会がそれ゙れ独自の計画を持ち，運営はクラブ員.

B : 全て厚生課. S : 部長仕 (T.M.)，厚生俰 (M.M.), レクリーダー及びクラブ (L.M.) とかなり組機的で,

M.M. が企画, L.M. が遗営を担当.

（4）I.S. B·S: 年度初めに年間の見通しを全従業員 に与えている. 各社とも P.S. の直前 (1 週〜1 ケ月) に 交書や放送で個々の P.S. の実施要項，程過，結果を報 せている.

（5）表彰の仕方，経镐などには多少差異が㑇められた か，Ath. P. の場合の競技形式実施時期，時間，利用施 設，場所などには顕著な差はなかった。

2. P.S.の動員率 運動生活調査から P.S. の動員 率をみると，K：男子 $43.5 \%$ ，女子 $25.8 \%$ ：：：男57.4 $\%$ ，女 $42.5 \%$. B : 男 $60.0 \%$ ，女 $56.6 \%$. S : 男 70.0 \%,女49.5\%であった。

以上のことから学校の場合について考兄て来た P.S. の程営理論は，耤場の場合にも有效であることが碓認で きた。

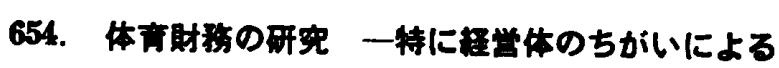
体青期弱の比校を中心に一

\section{東京教育大学 八代勉}

体育程営をささえる一要来としての体青財邪につい て、これまで学校を中心に研究をつつけてきたが，今回

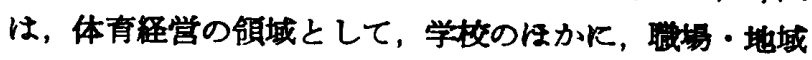
社会体育の領域について，その財務の実情を把握し，程 営体の特筫と体育財䅂との基本的関係を明らかにしょら とした．资料は昨年までの学校用查のほか，新たに訪問 調查を榴垉・地城社会について実施した，結果の概要は 次の通りである，学校は，体育に最す深い関保を持つ教 育释営体を体侍ち，法的にも守られ，体育事莱が最 あバランス上く行われる可能性を持つ程営体である. 財

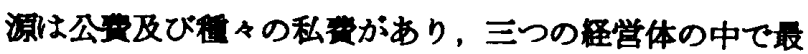

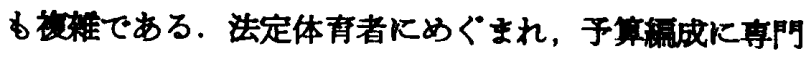
性を発挥でき，効果的支出が期待できるのる，他の程営

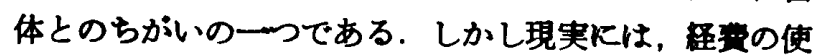
い方には問題点す多い.

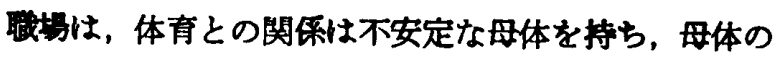
释営体の意志や関心によって左右されやすく，体育財邪

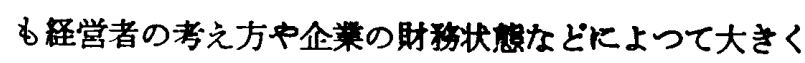
左右されるし，予算編成の面でる，体有の事門的知識を 持つた予算立案者がいないため，程费の效率的支出はあ まり期待できない，財源では，会社の支出金が大部分を 占め，さらに健保組合や，労伤組合などからの補助金か 多くみられる. その他, 会貝制をとり, 従莱员からの德 集金で財源を形成しているところるみられる．財源での 問題は，大企業と小企莱との格差が大であることが明ら かである. 程费の使梌は，C.S. 韧と P.S. 費で殆んどを 占め，A.S. 䫔は殆んどみられないのは，やはり問題て ある。地域社会は，近年体育との関保はかなり密接とな り，体育の指迸者む多くみられてきた。しかし首長の意 志・関心に左右されることる現実問通であり，必ずしる めぐまれた程営体ではない，公共団体の財政状䅧などK よつて格差かなりみられる．財源は全て公带でまかなわ れており，使途は A.S. 费が最す多く，P.S. 䩀と次いて おり，C.S. 愣は殆んどない，以上三つの経営体の財務 の面からの特酸を简に述べたが，今後はそれぞれの释

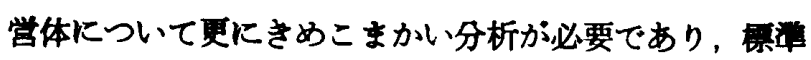
程㹂算出の必要性す出て来るであろう。 